\title{
Hotels
}

\section{Sustainable hotel business practices}

Received: 28 November 2005

\section{Elana E. Bader}

is a research analyst with the London office of HVS International, specialists in hotel valuation and consultancy. She joined the firm in September 2005 after completing a BSc in hotel administration at Cornell University.

\begin{abstract}
As global tourist arrival numbers continue increasing, demand and supply trends in regard to sustainable business practices are shifting. Individual travellers, organisations and banking consortia are changing perceptions about requirements for the future and the responsibilities that hotels carry regarding that future. Hotel owners and operators must adapt to these changes in order to satisfy demand and remain attractive to investors as well as operationally feasible and profitable. This paper is a surface examination of the benefits, especially economic, of sustainable business practices and sustainability trends in demand and supply.
\end{abstract}

\section{Keywords:}

hotels, sustainability, responsible business practices, profitability, demand

\section{INTRODUCTION}

The hospitality industry is gradually becoming the single greatest example of why running a sustainable business will be crucial for long-term success. Defined at the 1992 UN Conference on Environment and Development in Rio de Janeiro as 'meeting the needs of the present without compromising the ability of future generations to meet their own needs', sustainability is increasingly becoming one of the most relevant issues to hoteliers in the 21st century as costs continue to rise, demand becomes increasingly sensitive and the pressure on being economically, socially and environmentally responsible grows.

Hotels are not destinations as such. On the contrary, tourists stay at a hotel because it is proximate to what they wish to experience and it satisfies their lodging and personal requirements. Hoteliers are therefore accountable for responsible business practices because their continued existence is reliant on their environment. Hoteliers are coming to understand that only by preserving what is around them, in essence what is the reason for and source of their profit, can they truly preserve their business. 


\section{BENEFITS AND MOTIVATING FACTORS}

Hotels are highly dependent on successful financial performance from continuous demand and minimal costs for survival.

Sustainable practices can appear altruistic to the guest, shedding a positive light on a hotel. Furthermore, when applied correctly they are generally cost-effective with short periods of payback. Hotels implementing such measures are therefore financially sound investments as costs are recovered in a comparatively short time while long-term savings are great. So why have not all hotels been motivated to benefit from such measures?

One reason why the great majority of properties have not moved towards sustainable business practices is because they are not mainstream; only a small percentage of existing hotels, resorts and lodges have sustainability at the core of their business routine, and at very different levels of implementation. Another reason, stemming from the first, is simply a lack of public and industry awareness of the economic, social and environmental benefits enjoyed by those hotels with sustainable business practices.

There are many benefits for a hotel with sustainable business practices. Implemented to whatever degree desired, these practices make great financial differences.

- Cost saving through cost-reduction measures.

- Additional revenue through lower costs.

- Greater long-term financial stability.

- Greater attractiveness to lenders.

- Easier financing because of lower long-term risk.

- Long-term ability to stay in business and be profitable.

- Increased asset value because of long-term business capability.

In addition, positive PR created by marketing, recognition and awards can increase demand or even make new markets available to hotels. One potential future market may be the very one that demands sustainable practices in a vocal way.

By promoting and adhering to sustainable practices, hotels protect the very reason why guests come in the first place. The social and environmental practices appear altruistic to the general public; this perception, coupled with positive PR and financial stability, can increase demand, goodwill and, ultimately, general asset value.

\section{CURRENT DEMAND FOR SUSTAINABLE BUSINESS PRACTICES}

Latent demand for sustainable business practices in hotels is growing at both micro and macro levels. Direct demand is not so much of an indicator, as the sustainability of supply is not yet a mainstream issue in society. But hotel owners and operators are beginning to face differences in perception and recognition, from regional tourists in England to the International Finance Corporation (IFC). 
One fundamental similarity exists: the ever-louder call for responsible business practices. Various examples have proven that hotels adopting responsible, sustainable practices find an increase in business, profitability, repeat visitors and referrals. These are clear indicators that guests are aware of and support sustainable business practices in hotels.

\section{Micro demand}

In July 2005 Devon County Council in England conducted a survey of 5,000 actual and potential visitors, of whom 400 responded. The survey found that 54 per cent considered environmental issues when booking holidays, and 82 per cent would be prepared to pay more for environmentally responsible products. When asked if seeing an advert for a business with a green tourism business award would influence their decision to use that service, 72 per cent of those surveyed responded positively. ${ }^{1}$

One must appreciate the small sample size and understand that stating an interest in sustainability is not a substantiation of actual behaviour. But it can be inferred from this positive response that these individuals would actively choose to stay in hotels with sustainable business practices were these hotels more prevalent, accessible and marketed.

On a broader scale, many national and international organisations support, recognise and give awards to sustainable business practices in hospitality. The following are examples of such efforts.

- In England the International Tourism Partnership, a programme of the Prince of Wales International Business Leaders Forum, has created guidelines for sustainable hotel siting, construction and design. These guidelines aim at assisting hotel developers, owners and planners to create sustainable hotel developments and understand the long-term effects of their decisions. ${ }^{2}$

- In Switzerland the Ibex Label, developed by the Swiss Association for Economy, Ecology and Society, is given to hotels that 'convincingly display and document sustainable performance'. The principle criteria include basic management quality, adherence to environmental legislation and provision of information on structure and resource consumption. ${ }^{3}$

- In Costa Rica the Costa Rican Tourism Institute strongly supports sustainable development and created the Certificate in Sustainable Tourism, which 'categorizes and certifies each tourism company according to the degree to which its operations comply to a model of sustainability'.

- The International Hotel \& Restaurant Association (IH\&RA), in association with the UN Environment Programme, annually presents its Environmental Awards. These are some of the longest-running awards recognising the industry's proactive work in protecting the environment. 
- Several international magazines also award sustainable hospitality establishments, typically resorts and lodges. The Smithsonian Magazine annually presents the Sustainable Tourism Awards for conservation and preservation, and Condé Nast Traveller publishes the 'Green List', honouring resorts, lodges, tour operators and destinations.

Support, recognition and awards for sustainable business practices create positive awareness. This can act as a catalyst for demand, as guests are empowered to choose from a better selection of desirable and responsible hotels.

\section{Macro demand}

Tourism destinations and hotels are slowly facing increasing pressure from the growing number of global tourism arrivals, as shown in Figure 1. Additionally, the European Union (EU), market indices and lending banks are favouring responsible and sustainable businesses.

Tourism is the world's largest industry. In 2004763 million people travelled to a foreign country, up from 457 million in 1990, an increase of 67 per cent in just 14 years. Forecasts for the next 16 years predict an increase in world tourist arrival numbers of another 105 per cent, to 1.56 billion. This is a 242 per cent increase in 30 years. Although this figure is enormous, it must be understood that the growing number of tourist arrivals and the accompanying pressures will in all likelihood never cease. ${ }^{5}$

In order to keep up with these increasing pressures, hotel owners and operators must implement measures that will support the size of that demand. This means taking responsibility to minimise the impact such large numbers will inevitably have on the environment in which hotels operate. Failing to do so would mean partaking in the eventual destruction of their surroundings and therefore their business.

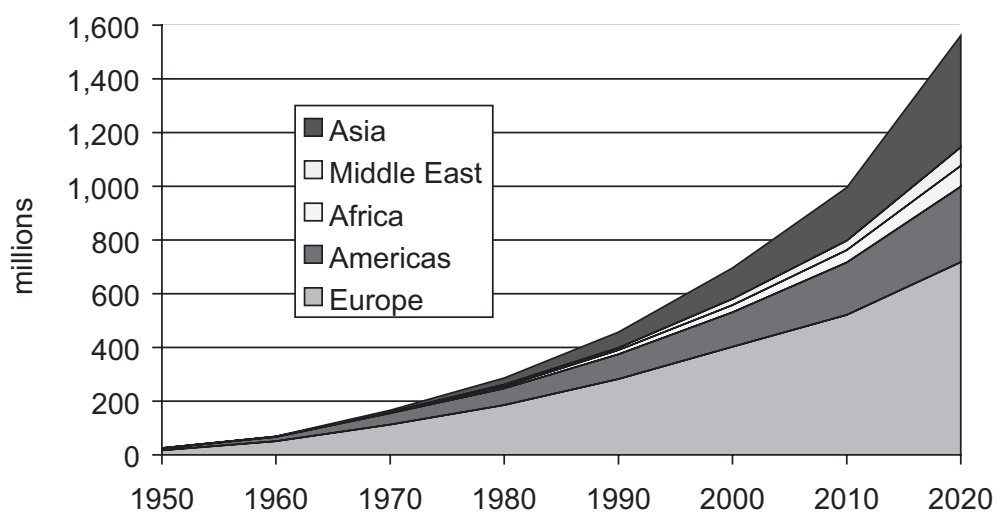

Figure 1: World tourist arrivals - actual and forecast

Source: World Tourism Organization 
Sustainability is not only a topic for individual hospitality businesses; it has also become an important aspect in the broader commercial marketplace. The FTSE4Good Index was introduced in 1995, and the Dow Jones Sustainability Index (DJSI) followed in 1999. These indices record the financial performance of the leading sustainability-driven companies and companies that meet globally recognised corporate responsibility standards, respectively. The reasoning behind them is twofold and most aptly described by the DJSI as follows.

'Firstly, the concept of corporate sustainability is attractive to investors because it aims to increase long-term shareholder value. Since corporate sustainability performance can now be financially quantified, they now have an investable corporate sustainability concept. Second, sustainability leaders are increasingly expected to show superior performance and favourable risk/return profiles. A growing number of investors is convinced that sustainability is a catalyst for enlightened and disciplined management, and, thus, a crucial success factor.' 6

This reasoning in the public marketplace can certainly be transposed to the hotel industry, as many corporate hotel companies have investors to satisfy as well. Accordingly, many global hotel companies are part of these indices: Accor,

InterContinental Hotels Group and Hilton Group are listed on the DJSI, and Accor, Hilton Group, InterContinental Hotels Group and Starwood are listed on the FTSE4Good Index.

The financing of hotels is also affected by how sustainable a development is. The Equator Principles were created in 2003 by leading financial institutions. They are a set of guidelines based on the IFC's environmental and social recommendations for project finance lenders in any industry sector. Currently more than 30 banking groups worldwide have publicly declared their incorporation of these principles, as they allow them to manage and record risk exposure by financing only those projects developed in a responsible manner. ${ }^{7}$

According to CMS, an alliance of major independent European law firms, banks accounting for more than three-quarters of the project loan market by volume have adopted the Equator Principles. ${ }^{8}$ With regard to hotels, the Equator Principles apply the IFC's guidelines for tourism and hospitality development. This means that large-scale hotel developments can run into difficulties if a project does not adhere to the Equator Principles and any other sustainability principles that a bank might enforce, as banks are free to append further guidelines as they see fit. On the other hand, a sustainable hotel project will be able to secure better financing faster, because it carries less risk in the long term and makes economic sense.

The EU is also pressuring for responsible business practices. 
Extended producer responsibility, or EPR, is forcing manufacturers to take responsibility for the environmental impact of their products, moving accountability away from end users and taxpayers towards producers. The pressure that EPR is placing on manufacturers also applies to hotels, meaning that the hospitality industry will be held accountable for its practices.

It appears that macro demand is feeding micro demand as organisations and banks are more vociferous in their requirements for hotel operations. These requirements are currently having a greater effect on hotels because they stem from financial and regulatory groups. On the other hand, the same demand for sustainable business practices from individual travellers or micromarkets is not as powerful in forcing hotels to change the ways in which they operate.

\section{CURRENT HOTEL SUPPLY AND SUSTAINABLE BUSINESS PRACTICES}

By the turn of the 20th century, sustainable hotel businesses existed in various degrees on each continent and in every conceivable location from cities to deserts and jungles. A number of global hotel companies have implemented sustainable business practices over the last ten years to a greater or lesser degree, as have an abundance of independent hotels, resorts and lodges. Accor, Fairmont, Marriott, Rezidor, Hilton, Starwood, Shangri-La and Taj Hotels and Resorts have all taken the first steps towards corporate hotel sustainability.

The following are three examples of hotel chains that have implemented sustainable business practices with financial success.

\section{Rezidor's Radisson SAS}

Rezidor counts 21 individual hotels from its Radisson SAS portfolio as best practice examples of responsible business policy implementation. These hotels have invested not only in various ways in their communities, but also in different cost-saving methods.

Particularly interesting are payback periods and the actual cost savings of certain systems. A steam recovery system in Beijing, China, had a three-month payback. Combined with a grey water system, the two systems result in annual savings of $€ 5,000$. An investment in 40 solar panels in Istanbul, Turkey, has a projected payback period of two years. In St Julian's, Malta, the solar energy system provides 25 per cent of the energy the resort needs to operate.

In Stavanger, Norway, two hotels were able to reduce energy consumption by 9 per cent in 2003 through a single energy-saving campaign; and in Dublin, Ireland, housekeeping has reduced chemical and laundry supplies by 50 per cent. ${ }^{9}$ 


\section{Hilton's Scandic}

Many of Hilton's franchise brands participate in Hilton's environmental efforts: Hilton, Doubletree, Embassy Suites Hotels, Hilton Garden Inn, Hampton Inn, Hampton Inn \& Suites, Hilton Grand Vacations, Homewood Suites and Scandic. But of these only Scandic has been proactive in making sustainability a corporate policy.

Scandic operates primarily in northern Europe and is one of the leaders in sustainable corporate hospitality business practices, not only in operations but also in construction and design. Every property takes part in the environmental efforts of the chain. The efficient use of resources alone has reduced water consumption by 13 per cent, energy consumption by 24 per cent and unsorted waste by 40 per cent, ${ }^{10}$ with the financial benefits of Scandic's environmental practices estimated to be in excess of $€ 7.6 \mathrm{~m}$ since 2003 . ${ }^{11}$

In 1995 Scandic introduced the 95 per cent recyclable, or biodegradable, room. The design won several awards, including the IH\&RA Environmental Award in 2002, and is slowly being rolled out to all hotels in the chain. Despite a fitting cost 10 per cent higher than a conventional room, resource consumption is dramatically lowered and guest demand for these rooms is higher.

\section{InterContinental and the Grand Stanford Hong Kong}

The InterContinental Grand Stanford Hong Kong has taken environmental concern further than many other hotels, with a clear environmental vision created in 1999. Initiatives since then have included installation of digital thermostats in all guest rooms, water purification systems, an ISO environmental management system and a building management system.

The hotel has greatly benefited from its actions and is estimated to have saved up to HK\$6m, over $€ 650,000$, between 1999 and October 2005. In addition, the hotel cites 'greater staff morale and dedication, and greatly improved hotel image due to the public relations value' as a result of these actions. The hotel also states that these results have 'led to a direct increase in business, as it has been proven that guests do base their hotel choice on a number of criteria - including environmental practices'. ${ }^{12}$

Since 2000 the hotel has been ISO14001 certified, meaning that it meets the environmental management standards of the International Organization for Standardization. Additionally, the hotel received the 2005 Eco-Hotel Champion Award from the Hong Kong Sustainable Communications Association because of its efforts to reduce energy consumption and waste emission.

\section{CONCLUSION}

Several corporate hoteliers have taken the first steps towards sustainable business practices. There is a growing understanding that these steps are crucial to ensure long-term business prospects and profitability. Current indicators also suggest that consumer and 
regulator demands are changing the business landscape for hoteliers, pushing them towards responsibility and implementation of sustainable business practices.

The economic, social and environmental benefits of correct implementation are established. To the hotelier, the most relevant of these are the economic. The financial implications of sustainable business practices are very tangible, as costs are reduced, profits rise, asset value increases and long-term success is ensured. In addition, the source of profitability, the environment, is also preserved; these are results that any knowledgable hotelier would covet.

It is therefore surprising that not more hotel owners and operators, especially corporate ones, are considering sustainability to be central to their business or incorporating it more deeply into their operating philosophies. What has been done so far in the hotel industry, especially by global companies, is a start. But it must be understood that deeper changes are required in the long term. The independent hotels, resorts and eco-lodges around the world that exist only for the sake of sustainability are taking the issue more seriously. This needs to be done globally, and the latent demand for responsible business practices is the first sign that it is beginning.

\section{References}

1. Discover Devon Naturally (2005) Discover Devon Tourism Survey, Devon County Council, Devon, UK.

2. International Tourism Partnership (2005) Sustainable Hotel Siting, Design and Construction, Prince of Wales International Business Leaders Forum, London, UK.

3. Braunschweig, A. and Saladino, D. (2004) The Sustainability Certification for Hotels, Association for Economy, Ecology and Society, Chur, Switzerland.

4. Sustainability Programs and the Costa Rica National Accreditation Commission (2005) Certification for Sustainable Tourism, Costa Rica Tourist Board, San José, Costa Rica.

5. World Tourism Organization (2005) Tourism Market Trends Annex, 2004 edn, WTO, Madrid, Spain.

6. Dow Jones Sustainability Index (2005) Sustainability Investment, available at www.sustainability-indexes.com/htmle/sustainability/sustinvestment.html, accessed November 2005.

7. International Finance Corporation, World Bank, ABN AMRO Bank, Barclays, Citigroup, Crédit Lyonnais, Credit Suisse First Boston, HVB Group, Rabobank Group, Royal Bank of Scotland, WestLB and Westpac Banking Corporation (2003) The Equator Principles - An Industry Approach for Financial Institutions in Determining, Assessing and Managing Environmental \& Social Risk in Project Financing, available at www.ifc.org/ifcext/equatorprinciples.nsf/content/theprinciples, accessed November 2005.

8. Sheridan, P. (2005) Issues Facing the Hotel Industry - Banks Apply Green Rules to Financing, CMS Legal, London, UK.

9. Rezidor (2005) Responsible Business Best Practice Examples, available at www.rezidor.com, accessed November 2005.

10. Scandic Hotels (2005) Ecological Sustainability at Scandic, Scandic Hotels, Stockholm, Sweden.

11. Bohdanowicz, P., Simanic, B. and Martinac, C. (2005) 'Environmental action in Scandic hotels', Independent Journal on Building and the Environment, Issue 01, p. 13.

12. InterContinental Grand Stanford Hong Kong (2005) Environmental Practices InterContinental Grand Stanford Hong Kong, InterContinental Grand Stanford, Hong Kong. 